\title{
From glucose lowering agents to disease/ diabetes modifying drugs: a "SIMPLE" approach for the treatment of type 2 diabetes
}

\author{
Ofri Mosenzon ${ }^{1,2^{*}}$ (D), Stefano Del Prato ${ }^{3}$, Meir Schechter ${ }^{1,2}$, Lawrence A. Leiter ${ }^{4}$, Antonio Ceriello ${ }^{5}$, \\ Ralph A. DeFronzo ${ }^{6}$ and Itamar Raz ${ }^{1,2}$
}

\begin{abstract}
During the last decade we experienced a surge in the number of glucose lowering agents that can be used to treat patients with type 2 diabetes. Especially important are the discoveries that sodium glucose co-transporter type 2 inhibitors (SGLT2i) and glucagon-like peptide-1 receptor agonists (GLP-1 RA) improve patients' cardiovascular and renal outcomes. Accordingly, various medical associations have updated their guidelines for the treatment of diabetes in this new era. Though not agreeing on every issue, these position-statements generally share a detailed and often complex workflow that may be too complicated for the busy and overworked primary care setting, where the majority of patients with type 2 diabetes are managed in many countries. Other guidelines, generally those from the cardiology associations focus primarily on the population of patients with high risk for or pre-existing cardiovascular disease, which represent only the minority of patients with type 2 diabetes. We believe that we should re-define SGLT2i and GLP-1 RA as diabetes/disease modifying drugs (DMDs) given the recent evidence of their cardiovascular and renal benefits. Based on this definition we have designed a SIMPLE approach in order to assist primary care teams in selecting the most appropriate therapy for their patients. We believe that most subjects newly diagnosed with type 2 diabetes should initiate early combination therapy with metformin and a prognosis changing DMD. The decision whether to use GLP-1 RA or SGLT2i should be made based on specific patient's risk factors and preferences. Importantly, DMDs are known to have a generally safe side-effect profile, with lower risk for hypoglycemia and weight gain, further promoting their wider usage. Early combination therapy with DMDs may improve the multiple pathophysiological abnormalities responsible for type 2 diabetes and its complications, thus resulting in the greatest long term benefits.
\end{abstract}

Keywords: Diabetes/Disease Modifying Drugs (DMDs), Type 2 Diabetes, Clinical approach

\footnotetext{
*Correspondence: ofrim@hadassah.org.il

${ }^{1}$ The Diabetes Unit, Department of Endocrinology and Metabolism, Hadassah Medical Center, P.O. Box 12000, 9112001 Jerusalem, Israel

Full list of author information is available at the end of the article
}

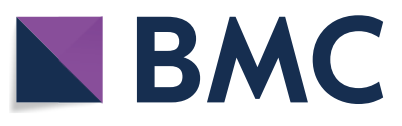

(c) The Author(s) 2021. This article is licensed under a Creative Commons Attribution 4.0 International License, which permits use, sharing, adaptation, distribution and reproduction in any medium or format, as long as you give appropriate credit to the original author(s) and the source, provide a link to the Creative Commons licence, and indicate if changes were made. The images or other third party material in this article are included in the article's Creative Commons licence, unless indicated otherwise in a credit line to the material. If material is not included in the article's Creative Commons licence and your intended use is not permitted by statutory regulation or exceeds the permitted use, you will need to obtain permission directly from the copyright holder. To view a copy of this licence, visit http://creativeco mmons.org/licenses/by/4.0/. The Creative Commons Public Domain Dedication waiver (http://creativecommons.org/publicdomain/ zero/1.0/) applies to the data made available in this article, unless otherwise stated in a credit line to the data. 


\section{Simple, Initial combination therapy, Multiple risk reduction, Primary care team, Life changing/ Prevention, re-Evaluation (Box 1)}

glucagon-like peptide-1 receptor agonists (GLP-1 RA)s and sodium glucose co-transporter type 2 inhibitors (SGLT2i) are DMDs [9-17]. The benefit of DMDs extend

\section{The "SIMPLE" approach}

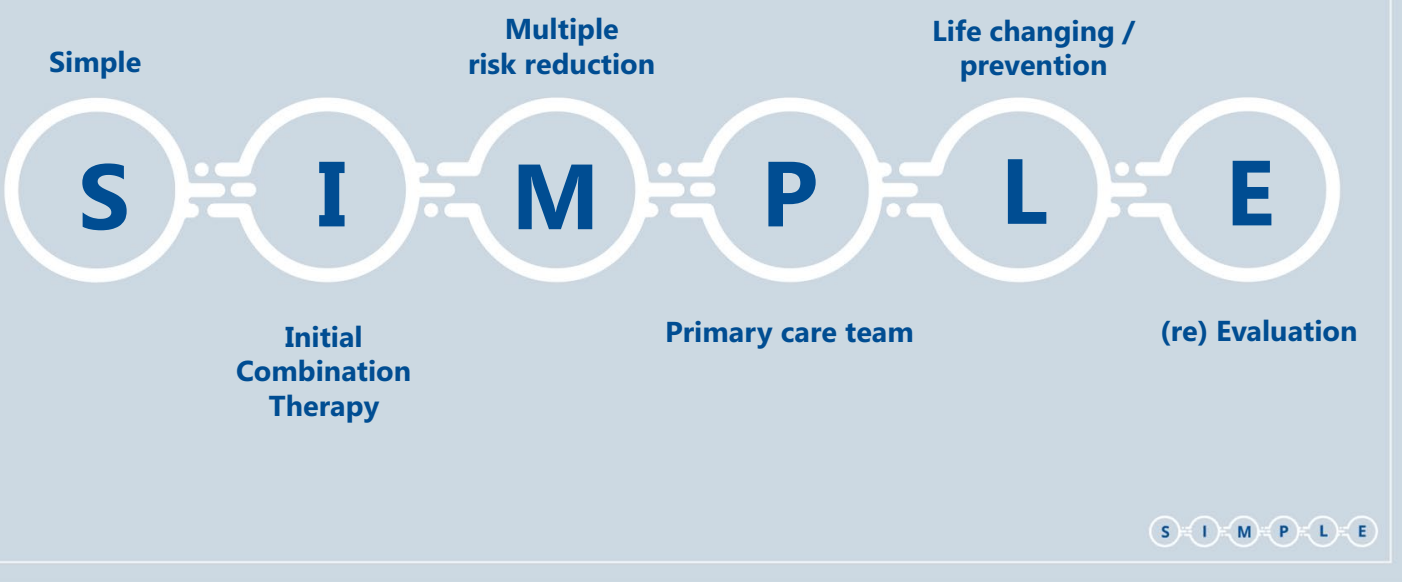

\section{Simple}

The new millennium has brought a new era to the treatment of type 2 diabetes, with a surge in the number of available therapies [1]. Concomitantly, regulators have required pharmaceutical companies to demonstrate the cardiovascular (CV) safety of these new glucose lowering agents (GLAs), leading to a large number of completed cardiovascular outcomes trials (CVOTs) [2] which have generated vast amounts of new information. The position statements of the ADA/EASD [3, 4] ECS/EASD[5], $\mathrm{AACE} / \mathrm{ACE}[6]$ and many others [7] are generally quite complex and therefore applying them to a specific patient can be challenging and time consuming. Since the primary care teams manage most patients with type 2 diabetes and are very often pressed for time, this complexity is a major barrier limiting the implementation of these guidelines in common practice [8].

Based on recent literature we believe that this intricacy can be minimized. Recent advances have led to definition of a new family of medications which we term "diabetes/disease modifying drugs" (DMDs). DMDs are GLAs that have CV [including atherosclerotic cardiovascular disease (ASCVD) and/or heart failure (HF)] and/ or renal protective effects demonstrated in a large multicenter, multinational, randomized, placebo-controlled clinical trial (Fig. 1). According to this definition most far beyond their glucose control effect, and also include weight reduction. DMDs have a blood pressure lowering effect; SGLT2i through their function in the kidney and GLP-1 RAs probably through reduction in body weight. GLP-1 RAs may also improve liver function tests. Most importantly, DMDs exert robust beneficial effects on the kidney and on the heart as a result of these and other yet unknown mechanisms [18-24]. Most patients with type 2 diabetes across different sub-populations may benefit from DMDs; we should therefore strive to treat most type 2 diabetes patients with DMDs, even those without specific risk factors. This definition makes treatment approaches simpler and therefore more useful in the primary care setting. Here we propose a SIMPLE approach to the treatment of type 2 diabetes that is based on the recent development and characterization of DMDs.

\section{Initial combination therapy}

Many older GLAs have been associated with significant risk for hypoglycemia and weight gain, leading to a cautious step-wise treatment strategy often described as "treat to failure" i.e. treatment initiation with a single agent and adding a second one only after the loss of plasma glucose control [25]. This approach was supported by large trials (ACCORD, ADVANCE and VADT) that did not find significant advantages for intensive 


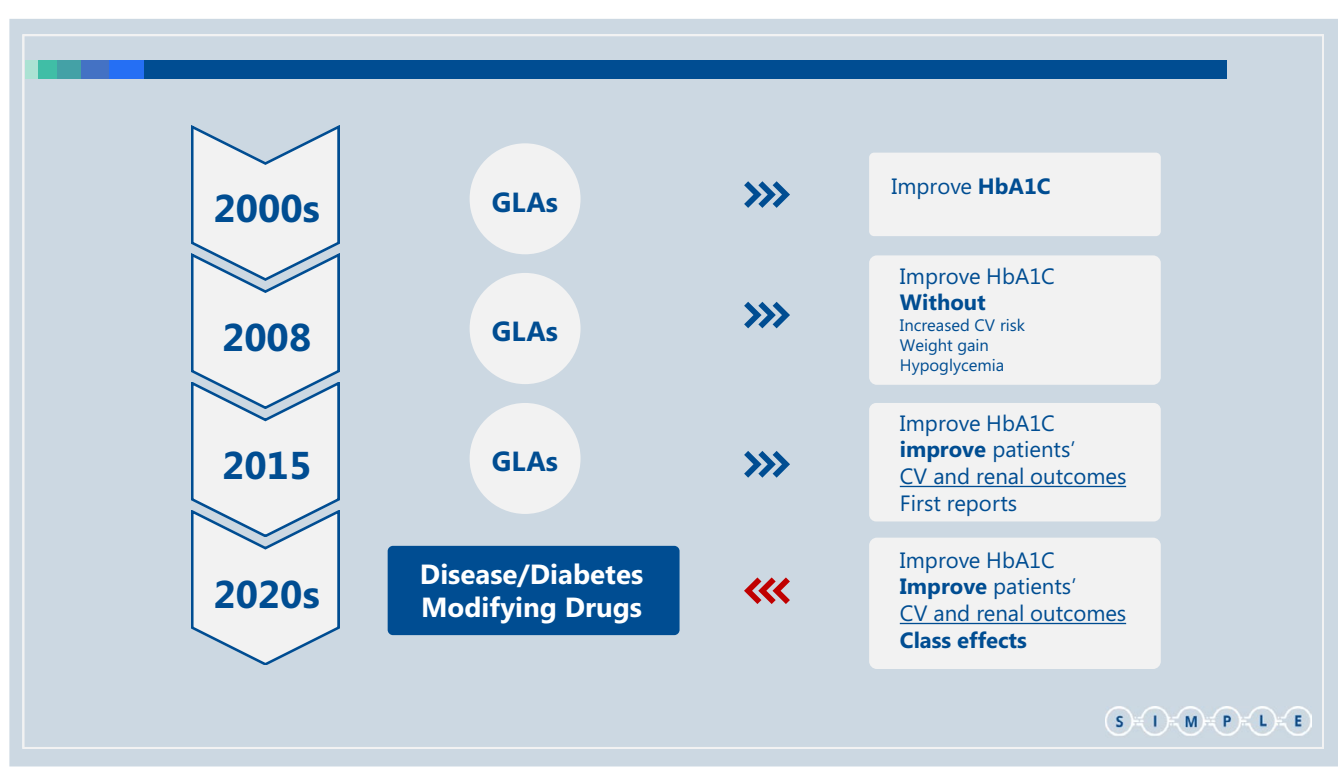

Fig. 1 Changes in the treatment of patients with type 2 diabetes over the last two decades. GLA Glucose Lowering Agents, CV Cardiovascular, FDA Food and Drugs Administration, DPP4i Dipeptidyl peptidase-4 inhibitors, SGLT2i Sodium glucose co-transporter type 2 inhibitor, GLP-1 RA Glucagon-like peptide-1 receptor agonists, DMD Disease/Diabetes modifying drug, MACE major adverse cardiovascular events. Until the early 2000s treatment of type 2 diabetes focused on glucose control. The main GLAs in use were insulin, metformin and sulfonylureas. In 2008, the FDA started to require pharmaceutical companies to confirm the CV safety of their newly developed GLAs, compared with placebo or other GLA, in patients with high CV risk [82]. Members of the DPP4i and thiazolidinediones classes were found to have CV non-inferiority, without CV superiority, in MACE-based outcomes [55, 83-86]. Starting in 2015, several members of the SGLT2i and GLP-1 RA classes were found to exert cardiorenal protection $[10-13,15-17,48,56]$, defining them as disease/diabetes modifying drug (DMDs)

glucose control (e.g. HbA1c below $6.0 \%$ or $6.5 \%$ ) in patients with relatively long diabetes duration (median of 8.0-11.5 years), on CV outcomes; this paradigm was especially relevant in patients with previous CVD [2628]. However, such practice may result in long periods in which patient's blood glucose levels are not well controlled, increasing the risk for future complications [29]. Newer DMDs, with beneficial effects on weight and lower occurrence of hypoglycemia, provide us with a valuable opportunity to harmonize the gluco- and cardiocentric approaches in diabetes management. We therefore argue for an "early combination" approach, starting with metformin and a DMD [30-32]. Importantly, this "early combination therapy" practice is well supported by up-to-date literature. DeFronzo and Abdul-Ghani demonstrated the beneficial effect of early combination therapy on markers of preservation of beta-cell function [33]. Furthermore, large retrospective cohorts [34, 35], a meta-analysis of 15 randomized controlled trials (RCT) $\mathrm{s}[36]$ as well as a recent large long-term RCT (the VERIFY trial)[31, 37] have all shown that early combination therapy leads to earlier, better and long-standing glucose control. The results of the NIH-supported GRADE study, an ongoing trial comparing different early combination therapies, will hopefully provide more information regarding the right composition for improved glucose control. However, the tested drugs include GLP-1 RA but not SGLT2i, and participation was not restricted to patients with newly diagnosed type 2 diabetes, resulting in an average baseline diabetes duration of approximately 4 years. Notably, RCTs data is lacking regarding the effect of early combination therapy on hard CV and kidney outcomes.

Thanks to the reduced risk of hypoglycemia with many agents including metformin, thiazolidinediones (TZDs), dipeptidyl peptidase 4 inhibitors (DPP4i), GLP-1 RA and SGLT2i, we advocate aiming for tighter glucose control. We acknowledge that the specific target HbA1c for most patients is still controversial, however until further research is conducted with safer DMDs, we generally suggest an $\mathrm{HbA} 1 \mathrm{c}$ target of $6.5 \%$ or lower. Of course, this should be done cautiously and according to patient's characteristics-excluding patients with history of severe hypoglycemia and those coping with comorbid conditions associated with frailty and/or limited life expectancy. Aiming for tighter glucose levels will enable longer intervals between visits, thereby reducing the risk for clinical inertia. Importantly, this target is supported by recent data indicating that more physiological plasma glucose levels at early stages limit glucose toxicity and intervene with other disease mechanisms-possibly halting its progression $[33,38,39]$. For example, in subjects 


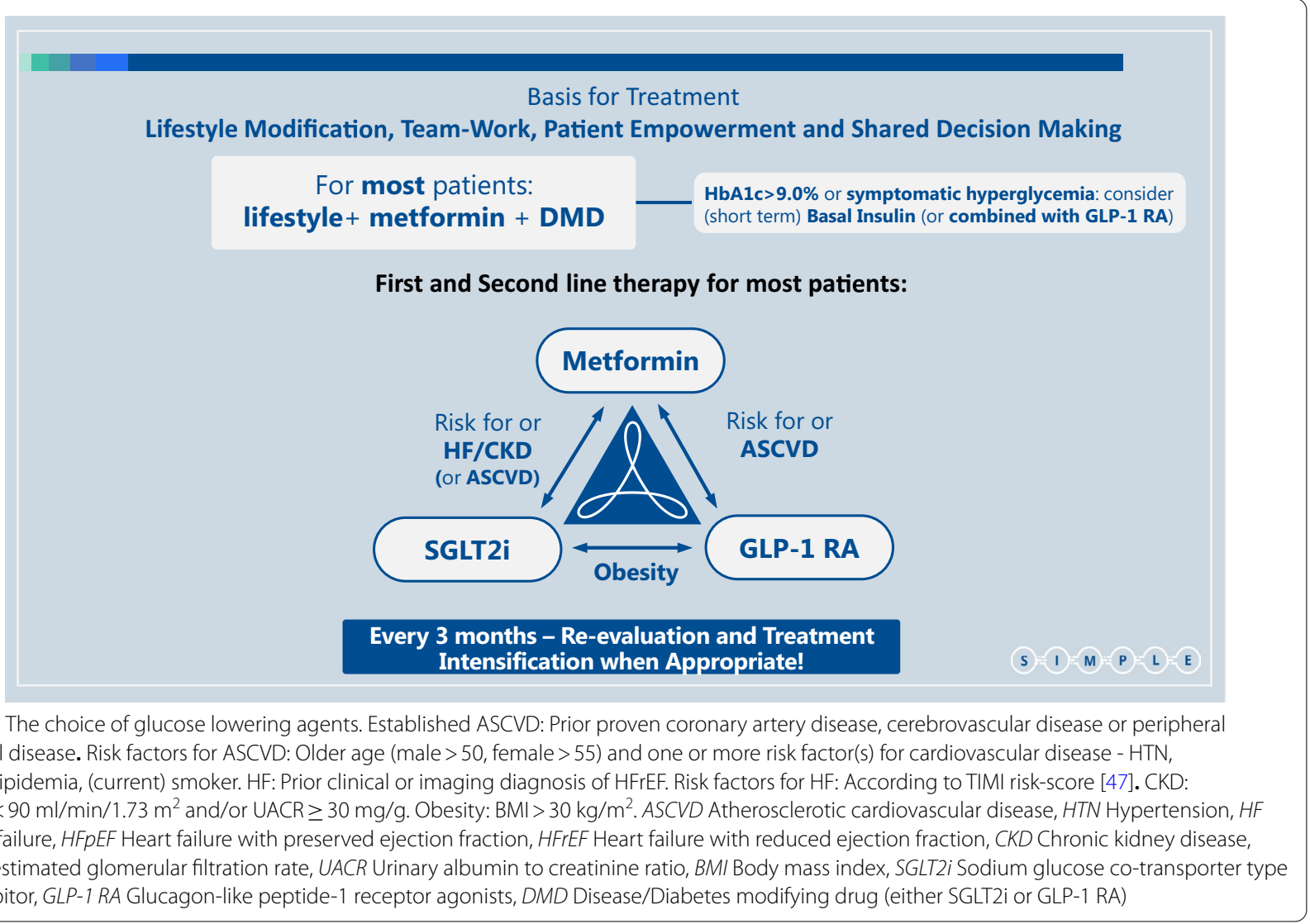

with pre-diabetes, reversion to normal glucose values, even temporarily, was associated with a marked delay in the incidence of diabetes, as well as improved beta-cell function and increased insulin sensitivity [38]. In patients with type 2 diabetes, longer periods of poor glycemic control was correlated with lower likelihood of attaining glycemic control once treatment was intensified [35]. Furthermore, early tight glucose control may be associated with lower rates of type 2 diabetes complications $[30,40]$. For instance, HbA1c $<6.5 \%$ during the first year from type 2 diabetes diagnosis, was recently associated with reduced risk for both microvascular and macrovascular complications, assessed during 10-years follow-up period [29]. Although the participants in these cohorts were mostly treated with older GLAs, similar studies with newer DMDs might yield similar or better results with lower concerns for side effects. It is time for earlier combination therapy, more physiological plasma glucose targets, and a stronger call to avoid the risk of treatment inertia.

We are aware of the recent controversy regarding the place of metformin in this new era of DMDs. Certainly, the great efficacy and safety of metformin over the years cannot and should not be overlooked. Relevantly, the
UKPDS trial demonstrated the CV efficacy of metformin, compared to the conventional therapy at the time, in a small number of patients [41, 42]. While in patients already treated with sulfonylureas, the addition of metformin was associated with a mild increase in diabetesrelated deaths [41]; however, in our approach we limit the use of sulfonylureas. It is important to note that all recent CVOTs with DMDs included about $80 \%$ of patients already treated with metformin.

Finally, we believe that there is a population of patients who require insulin therapy at diagnosis-specifically, those with symptomatic hyperglycemia and/ or $\mathrm{HbA} 1 \mathrm{c}>9.0 \%$ [43]. We are concerned that due to the wide spectrum of other therapeutic options, insulin use may be deferred even for those who can benefit from it at an early stage [44]. Importantly, recent data indicates that early combination of insulin and GLP-1 RA or other GLAs lead to better glycemic control $[45,46]$.

\section{Multiple risk reduction}

We propose a simple workflow to assist physicians and specifically primary care teams, in the process of drug selection (Fig. 2). It includes suggestions for early combination therapy, not only according to patient 
Table 1 Classes of glucose lowering agents: main findings of CVOTs and other important trials

\begin{tabular}{|c|c|c|c|c|}
\hline Group of drugs & Specific brands & Dosing & Comments & CVOTs / CROTs \\
\hline \multirow[t]{4}{*}{ SGLT2 inhibitors } & Canagliflozin & 100, 300 mg QD & $\begin{array}{l}\text { Proven reduction in 3-point MACE, hHF, all-cause } \\
\text { mortality and "hard" renal outcomes in popula- } \\
\text { tion of patients with/or risk factors for/ or previous } \\
\text { ASCVD, as well as in population of patients with } \\
\text { proteinuric diabetic nephropathy. Increased risk } \\
\text { for fractures and amputations in one outcome trial } \\
\text { (CANVAS) but not in the other (CREDENCE) }\end{array}$ & $\begin{array}{l}\text { CANVAS Program }[13,87] \\
\text { CREDENCE }[69]\end{array}$ \\
\hline & Dapagliflozin & 5, $10 \mathrm{mg}$ QD & $\begin{array}{l}\text { Proven reduction in hHF/CVD and "hard" renal } \\
\text { outcomes in population of patients with risk fac- } \\
\text { tors for/or previous ASCVD. Proven reduction in } \\
\text { CV death and hHF in populations of patients with } \\
\text { HFrEF with or without diabetes. Proven reduction } \\
\text { in a composite of clinically important kidney out- } \\
\text { comes and renal or CV death, in patients with CKD } \\
\text { with or without diabetes }\end{array}$ & $\begin{array}{l}\text { DECLARE-TIMI } 58[16,88] \\
\text { DAPA-HF }[89] \\
\text { DAPA-CKD }[70]\end{array}$ \\
\hline & Empagliflozin & 10,25 mg QD & $\begin{array}{l}\text { Proven reduction in 3-point MACE, CV death, hHF, all- } \\
\text { cause mortality and "hard" renal outcomes in popu- } \\
\text { lations of patients with previous ASCVD. Proven } \\
\text { reduction in CV death and hHF in populations of } \\
\text { patients with HFrEF with or without diabetes }\end{array}$ & $\begin{array}{l}\text { EMPA-REG } \\
\text { OUTCOME }[10,56] \\
\text { EMPEROR-Reduced [90] }\end{array}$ \\
\hline & Ertugliflozin & 5, $15 \mathrm{mg}$ QD & $\begin{array}{l}\text { CVOT in population of patients with ASCVD reported } \\
\text { CV safety both regarding 3-point MACE and CVD/ } \\
\text { hHF. Lower rate of hHF, and a trend towards } \\
\text { improved renal outcome }\end{array}$ & VERTIS-CV [48] \\
\hline $\begin{array}{l}\text { SGLT2 \& SGLT1 inhibi- } \\
\text { tor }\end{array}$ & Sotagliflozin & 200, 400 mg QD & $\begin{array}{l}\text { Reduction in CV death, hHF or urgent visit due to } \\
\text { HF in patients with type } 2 \text { diabetes and chronic } \\
\text { kidney disease (SCORED), or after a recent episode } \\
\text { of decompensated HF (SOLOIST-WHF). The stud- } \\
\text { ies were terminated early due to loss of funding. } \\
\text { Higher incidence of diarrhea was observed, as well } \\
\text { as genital mycotic infections, volume depletion, } \\
\text { and diabetic ketoacidosis (SCORED) or hypoglyce- } \\
\text { mic episodes (SOLOIST-WHF) }\end{array}$ & $\begin{array}{l}\text { SCORED [91] } \\
\text { SOLOIST-WHF [92] }\end{array}$ \\
\hline \multirow[t]{7}{*}{ GLP-1 receptor agonist } & Albiglutide & $30,50 \mathrm{mg}$ QW SC & $\begin{array}{l}\text { Proven reduction in 3-point MACE and CV death in } \\
\text { population of patients with risk factors for/or previ- } \\
\text { ous ASCVD. Currently not marketed }\end{array}$ & HARMONY Outcomes [15] \\
\hline & Dulaglutide & $0.75,1.5 \mathrm{mg} \mathrm{QW} \mathrm{SC}$ & $\begin{array}{l}\text { Proven reduction in 3-point MACE in population of } \\
\text { patients with risk factors for/or previous ASCVD. } \\
\text { Improvement in secondary renal composite } \\
\text { outcome }\end{array}$ & REWIND $[17,93]$ \\
\hline & Exenatide XR & $2 \mathrm{mg}$ QW SC & $\begin{array}{l}\text { Proven CV safety in population of patients with risk } \\
\text { factors for/ or previous ASCVD }\end{array}$ & EXSCEL [14] \\
\hline & Liraglutide & $1 \cdot 2-1 \cdot 8$ QD SC & $\begin{array}{l}\text { Proven reduction in 3-point MACE and CV death in } \\
\text { population of patients with risk factors (minority) or } \\
\text { with previous (majority) ASCVD }\end{array}$ & LEADER [11] \\
\hline & Lixisenatide & $10,20 \mathrm{mcg}$ QD SC & $\begin{array}{l}\text { Proven CV safety in population of patients with } \\
\text { recent acute coronary syndrome (ACS) }\end{array}$ & ELIXA [9] \\
\hline & Semaglutide & $0 \cdot 5,1 \mathrm{mg} \mathrm{QW} \mathrm{SC}$ & $\begin{array}{l}\text { A pre-approval trial demonstrated reduction in } \\
\text { 3-point MACE and CVA, but showed an increased } \\
\text { risk for worsening of retinopathy in population with } \\
\text { mostly ASCVD or CKD but some patients with only } \\
\text { CV risk factors. More effective than other GLP-1 RAs } \\
\text { in weight reduction and glucose control }\end{array}$ & SUSTAIN-6 [12] \\
\hline & Semaglutide (Oral) & 7, 14 mg QD PO & $\begin{array}{l}\text { In a smaller pre-approval trial, proven CV safety in } \\
\text { population of patients with risk factors for/or previ- } \\
\text { ous ASCVD. Demonstrated reduction in CV death } \\
\text { and all-cause mortality. A larger CVOT is ongoing }\end{array}$ & $\begin{array}{l}\text { PIONEER-6 [54] } \\
\text { SOUL [94] }\end{array}$ \\
\hline
\end{tabular}


Table 1 (continued)

\begin{tabular}{|c|c|c|c|c|}
\hline Group of drugs & Specific brands & Dosing & Comments & CVOTs / CROTs \\
\hline \multirow[t]{5}{*}{ DPP4- inhibitors } & Alogliptin & $12 \cdot 5,25 \mathrm{mg}$ QD & $\begin{array}{l}\text { Proven CV safety in population of patients with } \\
\text { recent ACS }\end{array}$ & EXAMINE [83] \\
\hline & Linagliptin & $5 \mathrm{mg}$ QD & $\begin{array}{l}\text { Proven CV safety in population of patients with risk } \\
\text { factors for/or previous ASCVD. No further CV ben- } \\
\text { efit over sulfonylurea (SU) }\end{array}$ & $\begin{array}{l}\text { CARMELINA [55] } \\
\text { CAROLINA [63] }\end{array}$ \\
\hline & Saxagliptin & $2 \cdot 5,5 \mathrm{mg} \mathrm{QD}$ & $\begin{array}{l}\text { Proven CV safety in population of patients with risk } \\
\text { factors for/or previous ASCVD. Increased risk for } \\
\text { hHF }\end{array}$ & SAVOR-TIMI 53 [84] \\
\hline & Sitagliptin & $25,50,100 \mathrm{mg}$ QD & $\begin{array}{l}\text { Proven CV safety in population of patients with previ- } \\
\text { ous ASCVD }\end{array}$ & TECOS [85] \\
\hline & Vildagliptin & $50 \mathrm{mg}$ BID & CV safety not tested & \\
\hline TZDs & Pioglitazone & $15,30,45$ mg QD & $\begin{array}{l}\text { Proven CV safety and possibly efficacy, reduced } \\
\text { 3-point MACE in patients with insulin resistance but } \\
\text { without diabetes after previous cerebrovascular } \\
\text { event. Increased risk of HF, weight gain, fractures in } \\
\text { post-menopausal women }\end{array}$ & $\begin{array}{l}\text { PROactive [95] } \\
\text { IRIS [86] }\end{array}$ \\
\hline \multirow[t]{2}{*}{ Insulin } & Degludec & & $\begin{array}{l}\text { Proven CV safety in population of patients with risk } \\
\text { factors for/or previous ASCVD }\end{array}$ & DEVOTE [96] \\
\hline & Glargine & & $\begin{array}{l}\text { Proven CV safety in population of patients with risk } \\
\text { factors for/or previous ASCVD, with diabetes or } \\
\text { pre-diabetes }\end{array}$ & ORIGIN [97] \\
\hline Biguanides & Metformin & & $\begin{array}{l}\text { Proven CV efficacy in small population of patients } \\
\text { with relatively new onset type } 2 \text { diabetes. In a sub- } \\
\text { group of patients treated with sulfonylurea, added } \\
\text { metformin was associated with increased diabetes } \\
\text { related death }\end{array}$ & UKPDS $[41,42]$ \\
\hline
\end{tabular}

ASCVD atherosclerotic cardiovascular disease, CKD chronic kidney disease, CROT cardiorenal outcome trial, CV cardiovascular, CVA cerebrovascular accident, CVD cardiovascular disease, CVOT cardiovascular outcome trial, DPP4i dipeptidyl peptidase 4 inhibitors, GLP-1 glucagon-like peptide-1, HFrEF heart failure with reduced ejection fraction, $h H F$ hospitalization for heart failure, MACE major adverse cardiovascular events, SGLT1 sodium glucose co-transporter type 1, SGLT2 sodium glucose co-transporter type 2, TZDs Thiazolidinediones

HbA1c but mainly according to his/her risk factors and co-morbidities.

We suggest a combination of SGLT2i with metformin in patients at increased risk for chronic kidney disease (estimated glomerular filtration rate (eGFR) $<90 \mathrm{ml} /$ $\mathrm{min} / 1.73 \mathrm{~m}^{2}$ and/or urinary albumin to creatinine ratio (UACR) $\geq 30 \mathrm{mg} / \mathrm{g}$ ) or for heart failure [according to TIMI-Hadassah risk score[47]] and possibly also in patients with established cardiovascular disease (eCVD)-although the effect of SGLT2i in the reduction of atherosclerotic events in patients with eCVD may be less consistent than previously thought, with the recent reporting of the non-inferiority results of the VERTIS-CV trial [48]. For patients at high risk for/or with ASCVD, we suggest a combination of metformin with GLP-1 RA (Fig. 2). A combination of GLP-1 RA and SGLT2i should be considered in patients where obesity is the main concern, although data on this is limited [49-52]. Of note, oral semaglutide is the first oral
GLP-1 RA that was recently approved by the Food and Drug Administration (FDA) [53]. This will hopefully lead to earlier and wider use of GLP-1 RA [54], with their proven advantages. Often a patient will eventually need the combination of all three groups of drugs: metformin + SGLT2i + GLP-1 RA.

In the process of selecting the right GLA $\backslash D M D$ within the same group of agents, we should keep in mind the between-drug variability, the specific populations in which the drug was investigated, and results obtained for each drug. Table 1 summarizes the main safety and efficacy findings obtained for each drug.

\section{Primary care team}

We suggest the following set of SIMPLE concepts, in order to make guidelines more useful for primary care teams, which treat most patients with type 2 diabetes (Box 2):

(1) The guidelines must be simple enough - so they can be easily applied. 


\section{Concepts of the "SIMPLE" approach to treat type 2 diabetes}

Must be simple

Take a proactive approach and avoid clinical inertia

Strive to treat most patients with a DMD (SGLT2i and/or GLP-1 RA).

Initiate combination therapy upon diagnosis of type $\mathbf{2}$ diabetes - mostly metformin and a DMD

Select specific DMD based on individual patient's risk factors and co-morbidities

HbA1c target should be as close to physiological ( $<6.5 \%$ and even lower) as possible (without side-

effects or interference with patient's quality of life).

GLP-1 RA should generally be the first injectable drug; however when HbA1c>9\% and/or patient has symptomatic hyperglycemia - consider treatment with basal insulin (possibly for short-term and $\backslash$ ror combined with GLP-1 RA).

When cost is an issue, metformin and pioglitazone are advisable.

In complex cases, consultation with a diabetes specialist is encouraged.

(2) Take a proactive approach and intensify treatment to meet patients' outcomes: avoid clinical inertia.

(3) We should strive to treat as many patients as possible (and not only those with previous ASCVD/ $\mathrm{HF} / \mathrm{CKD}$ ) with diabetes/disease modifying drugs (DMDs); i.e. SGLT2i and/or GLP-1 RA that demonstrate the best evidence of improving patients' prognosis.

(4) Initial combination therapy with metformin and a DMD (either SGLT2i or GLP-1 RA) (or DPP4i, if a DMD is not possible) should be considered for any patient upon diagnosis of type 2 diabetes.

(5) Specific DMD selection should rely on individual patient's risk factors and co-morbidities and existing evidence.

(6) Since DMDs do not increase the risk of hypoglycemia, aim for $\mathrm{HbA} 1 \mathrm{c}$ target that is as close to physiological ( $<6.5 \%$ and even lower) as can be achieved without side-effects or decline in patient's quality of life.

(7) GLP-1 RA should generally be the first injectable drug; however when $\mathrm{HbA} 1 \mathrm{c}>\mathbf{9 \%}$ and/or the patient has symptomatic hyperglycemia - treatment with basal insulin (possibly for a short-term and preferably combination of basal insulin and GLP-1 RA, either as free or fixed ratio combination [FRC]) should be considered.

(8) When cost is an issue, metformin and pioglitazone can be considered. However precautions should be taken when prescribing pioglitazone in patients who have a higher risk to develop HF or fractures. Use of sulfonylureas should be limited due to the relative high risk for side effects-hypoglycemia and weight gain (importantly, there is no clear evidence that they increase CV risk (55)).

(9) In complex cases or in patients with severe presentation, consider other forms of diabetes or concomitance with precipitating conditions. In these cases consultation with a diabetes specialist is encouraged.

This short paradigm aims to empower the primary physicians, as they treat the majority of patients with type 2 diabetes. Nonetheless, we cannot over emphasize the importance of a multidisciplinary team in the process. This team includes nurse-practitioners, nurses, dieticians, diabetes educators, social workers, and coaches. Diabetologists/endocrinologists and other specialists should also be involved according to specific patient's needs. All team members should cooperate to gain patient's trust, collaboration and compliance. Coexisting cardiorenal risk factors such as hypertension, hyperlipidemia, obesity and liver function should be well corrected, if possible; it is worth noting that SGLT2i and GLP-1 RAs exert positive effects on many of them [20-22]. Chiefly, the team should encourage patients to follow a healthy lifestyle as a foundation for every treatment regimen.

\section{Life changing/Prevention}

In 2015 we were all impressed by the first report that empagliflozin, an SGLT2i, may reduce cardiovascular (CV) and renal adverse outcomes $[10,56]$. Presently, we have strong evidence that DMDs (SGLT2i and GLP1 RA) are prognosis changing [9-17] in the sense that they can 
reduce diabetes related complications far beyond their glucose lowering effect. Furthermore, these benefits are well supported by analyses of real-life data [57-61], including an analysis that compared different add-on GLA therapies in metformin-treated patients with moderate CV risk [62]. Thus, "life/prognosis changing" DMDs should become the cornerstone in the treatment of any patients with type 2 diabetes (Figs. 1, 2).

We acknowledge that this approach has some limitations. Many practitioners find sulfonylureas safe and effective for specific patients, as supported by the recent CAROLINA study [63] where the incidence of MACE was similar between linagliptin (a DPP4i) and glimepiride (a sulfonylurea). In addition, linagliptin did not reduce MACE compared with placebo in the accompanying CARMELINA trial [55]. However, the occurrence of moderate-severe hypoglycemia at one year was $20 \%$ in the glimepiride group, compared with less than $5 \%$ in the linagliptin group. Moreover, a recent registry-based analysis showed that initiation of treatment with DMDs was associated with lower rates of adverse renal (and CV [58]) outcomes compared with DPP4i and even more when compared with sulfonylureas [61]. We therefore feel that the use of sulfonylureas should be limited.

We recognize the financial burden caused by the use of costly DMDs in wider populations, both on the patients' level and across all health systems and payers. This issue is specifically relevant in parts of the world that pressure on primary physicians to use less expensive drugs is greater. However, a large part of diabetes-associated expenditure is traced back to the cost of treating its complications $[64,65]$ which we hope to avoid or reduce with the use of these prognosis-changing agents. Cumulating data now support the cost-effectiveness of DMD use in different populations that participated in the CVOTs $[66,67]$. Of course, this notion should also be systematically investigated in cost-effectiveness analyses in a manner that is independent of interest groups. In addition, the patents for DMDs will eventually expire, for some of them sooner than the others, for example a generic version of liraglutide may become available in 2023. Besides its practical use, we hope that this approach, together with other guidelines, will assist in leading the medical community as well as policy makers towards better use of DMDs.

Treatment of patients with eGFR $<60 \mathrm{ml} / \mathrm{min} / 1.73 \mathrm{~m}^{2}$ requires further considerations. The lower glomerular filtration interferes with the glucose lowering effect of SGLT2i, yet their effect in improving hypertension, BMI and, most importantly, cardiorenal outcomes are still remarkable [68-70]. GLP-1 RAs were shown to be both safe and effective on improving glycemic control and BMI in several RCTs recruiting patients with eGFR $<60 \mathrm{ml} /$ $\mathrm{min} / 1.73 \mathrm{~m}^{2}$ [71-74].

Clinical judgement is necessary before prescribing DMDs. Caution is advised in SGLT2i treatment to those with high risk for diabetic ketoacidosis (DKA) or genital tract infections (GTIs). GLP-1 RAs should be avoided in patients with familial history of multiple endocrine neoplasia type 2 (MEN2) or medullary thyroid carcinoma, and precaution should be taken in patients that had idiopathic pancreatitis. We should also keep in mind that these are relatively new drugs, with little information regarding long term ( $>5$ years) safety. This paucity of data is partially compensated by the large number of participants in RCTs so far, allowing the detection of safety signals (e.g. increased risk for amputations in the CANVAS program [13], that have not been repeated in other trials). Registries should be constantly monitored for possibilities of yet unknown adverse effects. Yet, the current evidence is clear that the benefits of DMDs outweigh the risks.

As is generally accepted, the higher the background risk the higher the absolute risk reduction. Consequently, most CVOTs attempting to achieve statistically significant effects included patients with high CV- and renal risk, limiting our ability to extrapolate the results to lower risk populations. However, some more recent trials included patient populations without previous ASCVD, such as the DECLARE-TIMI 58 (reduction in hospitalization for HF with SGLT2i [16]) and REWIND (MACE reduction with GLP-1 RA [17]) trials, indicating a beneficial preventive effect for DMDs even in earlier stages of type 2 diabetes. Consequently, dulaglutide was the first type 2 diabetes medicine to receive FDA approval for the primary prevention of CVD in patients with type 2 diabetes [75]. Furthermore, recent registry-based analyses indicate that initiation of DMDs is associated with better renal outcomes across all tested subgroups, including patients with normal kidney function at baseline [59-61].

A recent analysis suggested that about a third of patients with type 2 diabetes are also diagnosed with CVD [76]. However, the true prevalence might be even higher and is related to differences in screening strategies across health systems. The global burden of diabetes-related end stage kidney disease (ESKD) has increased in the past decades, and other diabetes related complications affect millions worldwide [77]. Applying DMDs only to patients with established risk factors will undoubtedly miss many that evidently benefit from these drugs i.e. those that their high risk status was overlooked due to incomplete detection rate. All in all, the place and mission of DMDs in type 2 diabetes should be expanded from treatment of hyperglycemia to prevention of cardiovascular and kidney disease. 


\section{(re)-Evaluation}

Re-evaluation of patient's therapy and treatment targets are needed on a regular basis to avoid clinical inertia $[25,78]$, and treatment approaches should provide the primary care team with easy tools. The decision to initiate injective therapy is an example of a situation that can make the primary care team confused or hesitant: a simple workflow can assist in the process.

In current practice most patients use basal insulin as their first injectable drug, with only a small proportion starting with a GLP-1 RA. We concur with the ADA/ EASD guidelines, suggesting flipping the pyramid upside down: most patients should commence with a GLP-1 RA injection and only a minority should start with basal insulin as the first injectable (including patients with symptomatic hyperglycemia and/or $\mathrm{HbA} 1 \mathrm{c}>9.0 \%$, as above). When the "first injection" does not suffice to control plasma glucose levels, treatment should be titrated and if needed intensified. This can be done either by the addition of insulin (or by transferring to fixed ratio combination-FRC) in patients treated with GLP-1 RA, or by the addition of GLP-1 RA (or transferring to FRC) when a patient is treated with basal insulin (Fig. 3).

Importantly, most of those requiring insulin should be considered for treatment with a combination of GLP-1 RAs-either as free combination or as FRC. Such a combination of injectable drugs has various advantages: it provides better glucose normalization with less hypoglycemic events compared with basal insulin and does not cause similar weight gain to the extent observed with basal insulin $[79,80]$. It is also well tolerated and is associated with a lower rate of gastrointestinal side effects due to the slow titration, compared with GLP-1 RA alone [80]. However, since patients treated with insulin/GLP-1 RA combination tend have increased risk for hypoglycemia and increased weight gain than with GLP-1 RA alone, we do not recommend this combination as the first injectable but rather GLP-1 RA for most patients.

Due to the wide range of better options, short acting insulin therapy is moved down to the end of the list. Its usage in patients with type 2 diabetes should be carefully evaluated considering its advantages in glucose control compared with its side effects including high risk of hypoglycemia, weight gain and lower quality of life [81].

Lastly, management of patients with difficult to control diabetes requires special attention. Type 2 diabetes is still too often considered a condition resulting from poor adherence to lifestyle rather than a disease per se. Thus, consulting with a diabetes specialist is encouraged in patients that do not achieve glycemic control or in those with unique or alarming clinical features.

\section{Conclusions}

Since the busy primary care teams treat most patients with type 2 diabetes world-wide, treatment approaches should be as simple and convenient as possible. Yet, the recent increase in good therapy options, the surge of relevant data, and the need to "personalize"

\section{Choosing injectable drugs for patients with type 2 diabetes:}

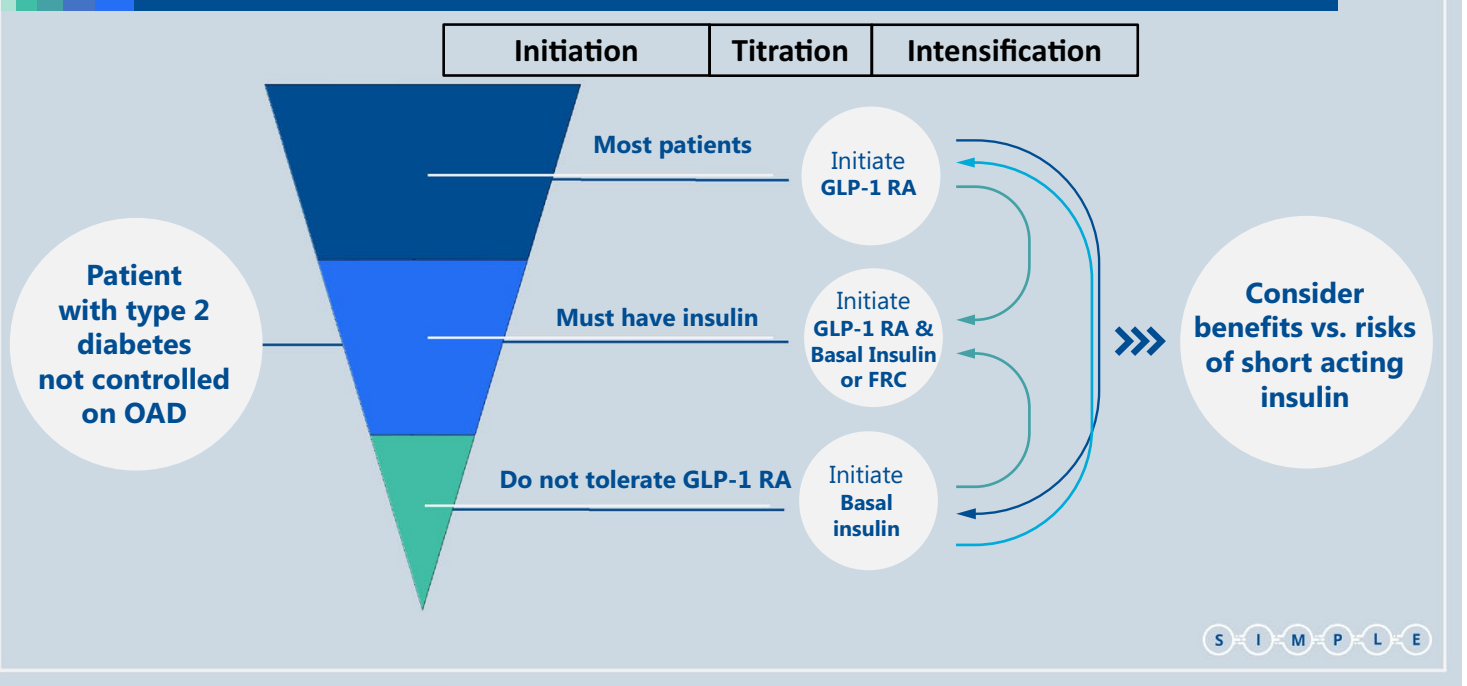

Fig. 3 Choosing injectable drugs for patients with type 2 diabetes. OAD Oral antidiabetic drug, GLP-1 RA Glucagon-like peptide-1 receptor agonist 
treatment-including their risk factors and possible cardiorenal complications-make this mission more complex than ever before. The development and characterization of the Diabetes $\backslash$ Disease Modifying Drugs provide us with a golden opportunity to simplify the treatment of type 2 diabetes, while reducing the disease's complications. Early combination therapy with two and sometimes three of the DMDs (SGLT2i and GLP-1 RA) and metformin, and lower HbA1c targets $(<6.5 \%)$, may halt and even regress the pathological basis of diabetes and improve patient's prognosis.

\begin{abstract}
Abbreviations
ASCVD: Atherosclerotic cardiovascular disease; CV: Cardiovascular; CVD: Cardiovascular disease; CVOTs: Cardiovascular outcomes trials; DKA: Diabetic ketoacidosis; DMDs: Diabetes/disease modifying drugs; DPP4i: Dipeptidyl peptidase 4 inhibitors; eGFR: Estimated glomerular filtration rate; ESKD: End stage kidney disease; FDA: Food and Drug Administration; FRC: Fixed ratio combination; GLAs: Glucose lowering agents; GLP-1 RA: Glucagon-like peptide-1 receptor agonists; GTI: Genital tract infection; HF: Heart failure; MACE: Major adverse cardiovascular event; MEN2: Multiple endocrine neoplasia type 2; RCT: Randomized controlled trial; SGLT2i: Sodium glucose co-transporter type 2 inhibitors; TZD: Thiazolidinedione; UACR: Urinary albumin to creatinine ratio.
\end{abstract}

\section{Acknowledgements}

We would like to express our gratitude to Ms. Rebecca Sprung for editing the manuscript and providing critical review.

\section{Authors' contributions}

$\mathrm{OM}$ and IR conceived the ideas. OM and MS wrote the initial draft and subsequent versions, and designed figures. IR, LAL, AC, RAD and SDP reviewed the manuscript and provided critical comments. All authors provided references from the literature, read, and approved the final version. No medical writer or editor was involved in this manuscript. All authors read and approved the final manuscript.

\section{Funding}

The authors received no specific funding for this work.

\section{Availability of data and materials}

Data sharing not applicable to this article as no datasets were generated or analysed during the current study.

\section{Declarations}

Ethics approval and consent to participate

Not applicable.

\section{Consent for publication}

Not applicable.

\section{Competing interests}

OM declares advisory board membership from AstraZeneca, Novo Nordisk, Eli Lilly, Sanofi, Merck Sharp \& Dohme, Boehringer Ingelheim; Speaker's bureau honorarium from AstraZeneca, Novo Nordisk, Eli Lilly, Sanofi, Merck Sharp \& Dohme, Boehringer Ingelheim, and Jansen; and research grants from Novo Nordisk and AstraZeneca.SDP declares advisory board membership from Astra Zeneca; Boehringer Ingelheim; Eli Lilly and Co; GlaxoSmithKline; Merck \& Co.; Novartis Pharmaceuticals; Novo Nordisk; sanofi; speaking commitments for Astra Zeneca; Boehringer Ingelheim; Eli Lilly and Co; Merck \& Co.; Novartis Pharmaceuticals; Novo Nordisk; Sanofi, Takeda Pharmaceuticals; research support from Astra Zeneca; Boehringer Ingelheim.MS declares no conflict of interest.LAL has received research support from, has provided CME on behalf of, and/or has acted as an advisor to AstraZeneca, Boehringer Ingelheim, Eli
Lilly, GSK, Janssen, Lexicon, Novo Nordisk, Sanofi, and/or Servier.AC declares advisory board membership from BD, Eli Lilly, Mundipharma; speakers' bureau honorarium from Astra Zeneca, Berlin Chemie, Boehringer Ingelheim, Eli Lilly, Mundipharma, Novo Nordisk, Roche Diagnostics; research grant from Mitsubishi.RAD declares Advisory Board: Astra Zeneca, Novo Nordisk, Janssen, Boehringer-Ingelheim, Intarcia, Poxel—Honorarium Research Support: Boehringer-Ingelheim, Astra Zeneca, Janssen, Merck-Research Grant(Investigator) Speaker's Bureau: Novo-Nordisk, Astra Zeneca-Honorarium (Speaker).IR declares Advisory Board membership from AstraZeneca, Eli Lilly and Company, Merck Sharp \& Dohme, Novo Nordisk, Inc, Sanofi; Consultant fees from AstraZeneca, Insuline Medical, Medial EarlySign Ltd, CamerEyes Ltd, Exscopia, Orgenesis Ltd, BOL Pharma, Glucome Ltd, DarioHealth, Diabot, Concenter BioPharma, CuraLife Ltd; Speaker's Bureau honorarium from AstraZeneca, Eli Lilly and Company, Merck Sharp \& Dohme, Novo Nordisk, Inc., Sanofi and Stock/Shareholder interests from Glucome Ltd, Orgenesis Ltd, DarioHealth, CamerEyes Ltd, Diabot, BOL Pharma.

\section{Author details}

${ }^{1}$ The Diabetes Unit, Department of Endocrinology and Metabolism, Hadassah Medical Center, P.O. Box 12000, 9112001 Jerusalem, Israel. ${ }^{2}$ Faculty of Medicine, Hebrew University of Jerusalem, Jerusalem, Israel. ${ }^{3}$ Department of Clinical and Experimental Medicine, Section of Diabetes, Nuovo Ospedale Santa Chiara, University of Pisa, Pisa, Italy. ${ }^{4}$ Li Ka Shing Knowledge Institute, St. Michael's Hospital, University of Toronto, Toronto, Canada. ${ }^{5}$ IRCCS MultiMedica, Sesto San Giovanni, Milan, Italy. ${ }^{6}$ University of Texas Health Science Center at Houston, Houston, TX, USA.

Received: 29 January 2021 Accepted: 15 April 2021

Published online: 28 April 2021

\section{References}

1. Prattichizzo F, La Sala L, Rydén L, Marx N, Ferrini M, Valensi P, et al. Glucose-lowering therapies in patients with type 2 diabetes and cardiovascular diseases. Eur J Prev Cardiol. 2019;26:73-80.

2. Diabetes mellitus - evaluating cardiovascular risk in new antidiabetic therapies to treat type 2 diabetes | FDA [Internet]. https://www.fda.gov/ regulatory-information/search-fda-guidance-documents/diabetes-melli tus-evaluating-cardiovascular-risk-new-antidiabetic-therapies-treat-type2-diabetes. Accessed 23 Nov 2019.

3. Davies MJ, D'Alessio DA, Fradkin J, Kernan WN, Mathieu C, Mingrone $\mathrm{G}$, et al. Management of hyperglycemia in type 2 diabetes, 2018. A consensus report by the american diabetes association (ADA) and the european association for the study of diabetes (EASD). Diabetes Care. 2018:41(12):2669-701.

4. Buse JB, Wexler DJ, Tsapas A, Rossing P, Mingrone G, Mathieu C, et al. 2019 update to: management of hyperglycemia in type 2 diabetes, 2018. A consensus report by the american diabetes association (ADA) and the european association for the study of diabetes (EASD). Diabetes Care. 2020;43(2):487-93.

5. Cosentino F, Grant PJ, Aboyans V, Bailey CJ, Ceriello A, Delgado V, et al. 2019 ESC Guidelines on diabetes, pre-diabetes, and cardiovascular diseases developed in collaboration with the EASD. Eur Heart J. 2020;41(2):255-323.

6. Garber AJ, Abrahamson MJ, Barzilay JI, Blonde L, Bloomgarden ZT, Bush MA, et al. Consensus statement by the american association of clinical endocrinologists and american college of endocrinology on the comprehensive type 2 diabetes management algorithm - 2019 executive summary. Endocr Pract. 2019;25(1):69-100.

7. Carrasco-Sánchez FJ, Fernández-Rodríguez JM, Ena J, Gómez-Huelgas R, Carretero-Gómez J, en representación del Grupo de trabajo de Diabetes, Obesidad y Nutrición de la Sociedad Española de Medicina Interna. Medical treatment of type 2 diabetes mellitus: Recommendations of the Diabetes, Obesity and Nutrition Group of the Spanish Society of Internal Medicine. Rev Clin Esp. 2020. https://doi.org/10.1016/j.rce.2020.06.005.

8. Cheung A, Stukel TA, Alter DA, Glazier RH, Ling V, Wang X, et al. Primary care physician volume and quality of diabetes care: a population-based cohort study. Ann Intern Med. 2017;166(4):240-7. 
9. Pfeffer MA, Claggett B, Diaz R, Dickstein K, Gerstein HC, Køber LV, et al. Lixisenatide in patients with type 2 diabetes and acute coronary syndrome. N Engl J Med. 2015;373(23):2247-57.

10. Zinman B, Wanner C, Lachin JM, Fitchett D, Bluhmki E, Hantel S, et al. Empagliflozin, cardiovascular outcomes, and mortality in type 2 diabetes. N Engl J Med. 2015;373(22):2117-28.

11. Marso SP, Daniels GH, Brown-Frandsen K, Kristensen P, Mann JF, Nauck MA, et al. Liraglutide and cardiovascular outcomes in type 2 diabetes. N Engl J Med. 2016:375(4):311-22.

12. Marso SP, Bain SC, Consoli A, Eliaschewitz FG, Jódar E, Leiter LA, et al. Semaglutide and cardiovascular outcomes in patients with type 2 diabetes. N Engl J Med. 2016;375(19):1834-44.

13. Neal B, Perkovic V, Mahaffey KW, de Zeeuw D, Fulcher G, Erondu N, et al. Canagliflozin and cardiovascular and renal events in type 2 diabetes. N Engl J Med. 2017;377(7):644-57.

14. Holman RR, Bethel MA, Mentz RJ, Thompson VP, Lokhnygina Y, Buse JB, et al. Effects of once-weekly exenatide on cardiovascular outcomes in type 2 diabetes. N Engl J Med. 2017;377(13):1228-39.

15. Hernandez AF, Green JB, Janmohamed S, D'Agostino RB, Granger CB, Jones NP, et al. Albiglutide and cardiovascular outcomes in patients with type 2 diabetes and cardiovascular disease (Harmony Outcomes): a double-blind, randomised placebo-controlled trial. Lancet. 2018;392(10157):1519-29.

16. Wiviott SD, Raz I, Bonaca MP, Mosenzon O, Kato ET, Cahn A, et al. Dapagliflozin and cardiovascular outcomes in type 2 diabetes. N Engl J Med. 2019;380(4):347-57.

17. Gerstein HC, Colhoun HM, Dagenais GR, Diaz R, Lakshmanan M, Pais $P$, et al. Dulaglutide and cardiovascular outcomes in type 2 diabetes (REWIND): a double-blind, randomised placebo-controlled trial. Lancet. 2019;394(10193):121-30.

18. Heerspink HJL, Perkins BA, Fitchett DH, Husain M, Cherney DZI. Sodium glucose cotransporter 2 inhibitors in the treatment of diabetes mellitus: cardiovascular and kidney effects, potential mechanisms, and clinical applications. Circulation. 2016;134(10):752-72.

19. Inzucchi SE, Zinman B, Fitchett D, Wanner C, Ferrannini E, Schumacher M, et al. How does empagliflozin reduce cardiovascular mortality? Insights from a mediation analysis of the EMPA-REG OUTCOME trial. Diabetes Care. 2018:41(2):356-63.

20. Shao S-C, Chang K-C, Lin S-J, Chien R-N, Hung M-J, Chan Y-Y, et al. Favorable pleiotropic effects of sodium glucose cotransporter 2 inhibitors: head-to-head comparisons with dipeptidyl peptidase-4 inhibitors in type 2 diabetes patients. Cardiovasc Diabetol. 2020;19(1):17.

21. Newsome PN, Buchholtz K, Cusi K, Linder M, Okanoue T, Ratziu V, et al. A placebo-controlled trial of subcutaneous semaglutide in nonalcoholic steatohepatitis. N Engl J Med. 2020;384(12):1113-24.

22. Berra C, Manfrini R, Regazzoli D, Radaelli MG, Disoteo O, Sommese C, et al. Blood pressure control in type 2 diabetes mellitus with arterial hypertension. The important ancillary role of SGLT2-inhibitors and GLP1-receptor agonists. Pharmacol Res. 2020;160:105052.

23. Hu M, Cai X, Yang W, Zhang S, Nie L, Ji L. Effect of hemoglobin A1C reduction or weight reduction on blood pressure in glucagon-like peptide-1 receptor agonist and sodium-glucose cotransporter-2 inhibitor treatment in type 2 diabetes mellitus: a meta-analysis. J Am Heart Assoc 2020;9(7):e015323.

24. Sen T, Heerspink HJL. A kidney perspective on the mechanism of action of sodium glucose co-transporter 2 inhibitors. Cell Metab. 2021. https:// doi.org/10.1016/j.cmet.2021.02.016.

25. Del Prato S, Felton AM, Munro N, Nesto R, Zimmet P, Zinman B, et al. Improving glucose management: ten steps to get more patients with type 2 diabetes to glycaemic goal. Int J Clin Pract. 2005;59(11):1345-55.

26. ACCORD Study Group, Gerstein HC, Miller ME, Byington RP, Goff DC, Bigger JT, et al. Effects of intensive glucose lowering in type 2 diabetes. $N$ Engl J Med. 2008;358(24):2545-59.

27. ADVANCE Collaborative Group, Patel A, MacMahon S, Chalmers J, Neal B, Billot $L$, et al. Intensive blood glucose control and vascular outcomes in patients with type 2 diabetes. N Engl J Med. 2008:358(24):2560-72.

28. Duckworth W, Abraira C, Moritz T, Reda D, Emanuele N, Reaven PD, et al. Glucose control and vascular complications in veterans with type 2 diabetes. N Engl J Med. 2009;360(2):129-39.

29. Laiteerapong N, Ham SA, Gao Y, Moffet HH, Liu JY, Huang ES, et al. The legacy effect in type 2 diabetes: impact of early glycemic control on future complications (the diabetes \& aging study). Diabetes Care. 2019;42(3):416-26.

30. Defronzo RA. Banting Lecture. From the triumvirate to the ominous octet: a new paradigm for the treatment of type 2 diabetes mellitus. Diabetes. 2009;58(4):773-95.

31. Mosenzon O, Leibowitz G. VERIFY the role of initial combination therapy in patients with type 2 diabetes. Lancet. 2019;394(10208):1483-5.

32. Prattichizzo F, La Sala L, Ceriello A. Two drugs are better than one to start T2DM therapy. Nat Rev Endocrinol. 2020;16(1):15-6.

33. Abdul-Ghani MA, Puckett C, Triplitt C, Maggs D, Adams J, Cersosimo $E$, et al. Initial combination therapy with metformin, pioglitazone and exenatide is more effective than sequential add-on therapy in subjects with new-onset diabetes. Results from the Efficacy and Durability of Initial Combination Therapy for Type 2 Diabetes (EDICT): a randomized trial. Diabetes Obes Metab. 2015;17(3):268-75.

34. Khunti K, Wolden ML, Thorsted BL, Andersen M, Davies MJ. Clinical inertia in people with type 2 diabetes: a retrospective cohort study of more than 80,000 people. Diabetes Care. 2013;36(11):3411-7.

35. Desai U, Kirson NY, Kim J, Khunti K, King S, Trieschman E, et al. Time to treatment intensification after monotherapy failure and its association with subsequent glycemic control among 93,515 patients with type 2 diabetes. Diabetes Care. 2018;41(10):2096-104.

36. Phung OJ, Sobieraj DM, Engel SS, Rajpathak SN. Early combination therapy for the treatment of type 2 diabetes mellitus: systematic review and meta-analysis. Diabetes Obes Metab. 2014;16(5):410-7.

37. Matthews DR, Paldánius PM, Proot P, Chiang Y, Stumvoll M, Del Prato $S$, et al. Glycaemic durability of an early combination therapy with vildagliptin and metformin versus sequential metformin monotherapy in newly diagnosed type 2 diabetes (VERIFY): a 5-year, multicentre, randomised, double-blind trial. Lancet. 2019. https://doi.org/10.1016/S0140-6736(19) 32131-2.

38. Perreault L, Pan Q, Mather KJ, Watson KE, Hamman RF, Kahn SE, et al. Effect of regression from prediabetes to normal glucose regulation on long-term reduction in diabetes risk: results from the Diabetes Prevention Program Outcomes Study. Lancet. 2012;379(9833):2243-51.

39. Rossetti L, Giaccari A, DeFronzo RA. Glucose toxicity. Diabetes Care. 1990;13(6):610-30.

40. Ceriello A, Ihnat MA, Thorpe JE. Clinical review 2: The "metabolic memory": is more than just tight glucose control necessary to prevent diabetic complications? J Clin Endocrinol Metab. 2009;94(2):410-5.

41. Effect of intensive blood-glucose control with metformin on complications in overweight patients with type 2 diabetes (UKPDS 34). UK Prospective Diabetes Study (UKPDS) Group. Lancet. 1998;352(9131):854-865.

42. Holman RR, Paul SK, Bethel MA, Matthews DR, Neil HAW. 10-year follow-up of intensive glucose control in type 2 diabetes. N Engl J Med. 2008:359(15):1577-89.

43. Babu A, Mehta A, Guerrero P, Chen Z, Meyer PM, Koh CK, et al. Safe and simple emergency department discharge therapy for patients with type 2 diabetes mellitus and severe hyperglycemia. Endocr Pract. 2009;15(7):696-704.

44. Raz I, Mosenzon O. Early insulinization to prevent diabetes progression. Diabetes Care. 2013;36(Suppl 2):S190-7.

45. Rosenstock J, Ampudia-Blasco FJ, Lubwama R, Peng XV, Boss A, Shi L, et al. Real-world evidence of the effectiveness on glycaemic control of early simultaneous versus later sequential initiation of basal insulin and glucagon-like peptide-1 receptor agonists. Diabetes Obes Metab. 2020;22(12):2295-304.

46. Peng XV, Ayyagari R, Lubwama R, Shi L, Price-Haywood EG, Hollander $P$, et al. Impact of simultaneous versus sequential initiation of basal insulin and glucagon-like peptide-1 receptor agonists on $\mathrm{HbA1}$ in type 2 diabetes: a retrospective observational study. Diabetes Ther. 2020;11(4):995-1005

47. Berg DD, Wiviott SD, Scirica BM, Gurmu Y, Mosenzon O, Murphy SA, et al. Heart failure risk stratification and efficacy of sodium-glucose cotransporter-2 inhibitors in patients with type 2 diabetes mellitus. Circulation. 2019;140(19):1569-77.

48. Cannon CP, Pratley R, Dagogo-Jack S, Mancuso J, Huyck S, Masiukiewicz $\mathrm{U}$, et al. Cardiovascular outcomes with ertugliflozin in type 2 diabetes. N Engl J Med. 2020;383(15):1425-35.

49. Zinman B, Bhosekar V, Busch R, Holst I, Ludvik B, Thielke D, et al. Semaglutide once weekly as add-on to SGLT-2 inhibitor therapy in type 2 diabetes 
(SUSTAIN 9): a randomised, placebo-controlled trial. Lancet Diabetes Endocrinol. 2019;7(5):356-67.

50. Ludvik B, Frías JP, Tinahones FJ, Wainstein J, Jiang H, Robertson KE, et al. Dulaglutide as add-on therapy to SGLT2 inhibitors in patients with inadequately controlled type 2 diabetes (AWARD-10): a 24-week, randomised, double-blind, placebo-controlled trial. Lancet Diabetes Endocrinol. 2018;6(5):370-81.

51. Frías JP, Guja C, Hardy E, Ahmed A, Dong F, Öhman P, et al. Exenatide once weekly plus dapagliflozin once daily versus exenatide or dapagliflozin alone in patients with type 2 diabetes inadequately controlled with metformin monotherapy (DURATION-8): a 28 week, multicentre, doubleblind, phase 3, randomised controlled trial. Lancet Diabetes Endocrinol. 2016:4(12):1004-16.

52. Blonde L, Belousova L, Fainberg U, Garcia-Hernandez PA, Jain SM, Kaltoft MS, et al. Liraglutide as add-on to SGLT2 inhibitors in patients with inadequately controlled type 2 diabetes: LIRA-ADD2SGLT2i, a 26-week, randomized, double-blind, placebo-controlled trial. Diabetes Obes Metab. 2020. https://doi.org/10.1111/dom.13978.

53. FDA approves first oral GLP-1 treatment for type 2 diabetes | FDA [Internet]. https://www.fda.gov/news-events/press-announcements/fda-appro ves-first-oral-glp-1-treatment-type-2-diabetes. Accessed 23 Nov 2019.

54. Husain M, Birkenfeld AL, Donsmark M, Dungan K, Eliaschewitz FG, Franco $\mathrm{DR}$, et al. Oral semaglutide and cardiovascular outcomes in patients with type 2 diabetes. N Engl J Med. 2019;381 (9):841-51.

55. Rosenstock J, Perkovic V, Johansen OE, Cooper ME, Kahn SE, Marx N, et al. Effect of linagliptin vs placebo on major cardiovascular events in adults with type 2 diabetes and high cardiovascular and renal risk: the CARMELINA randomized clinical trial. JAMA. 2019;321(1):69-79.

56. Wanner C, Inzucchi SE, Lachin JM, Fitchett D, von Eynatten M, Mattheus $M$, et al. Empagliflozin and progression of kidney disease in type 2 diabetes. N Engl J Med. 2016:375(4):323-34.

57. Kosiborod M, Cavender MA, Fu AZ, Wilding JP, Khunti K, Holl RW, et al. Lower risk of heart failure and death in patients initiated on sodium-glucose cotransporter-2 inhibitors versus other glucose-lowering drugs: the CVD-REAL study (Comparative Effectiveness of Cardiovascular Outcomes in New Users of Sodium-Glucose Cotransporter-2 Inhibitors). Circulation. 2017;136(3):249-59.

58. Kohsaka S, Lam CSP, Kim DJ, Cavender MA, Norhammar A, Jørgensen ME, et al. Risk of cardiovascular events and death associated with initiation of SGLT2 inhibitors compared with DPP-4 inhibitors: an analysis from the CVD-REAL 2 multinational cohort study. Lancet Diabetes Endocrinol. 2020:8(7):606-15.

59. Heerspink HJL, Karasik A, Thuresson M, Melzer-Cohen C, Chodick G, Khunti K, et al. Kidney outcomes associated with use of SGLT2 inhibitors in real-world clinical practice (CVD-REAL 3): a multinational observational cohort study. Lancet Diabetes Endocrinol. 2020;8(1):27-35.

60. Xie Y, Bowe B, Gibson AK, McGill JB, Yan Y, Maddukuri G, et al. Comparative effectiveness of the sodium-glucose cotransporter 2 inhibitor empagliflozin versus other antihyperglycemics on risk of major adverse kidney events. Diabetes Care. 2020. https://doi.org/10.2337/dc20-1231.

61. Xie Y, Bowe B, Gibson AK, McGill JB, Maddukuri G, Yan Y, et al. Comparative effectiveness of SGLT2 inhibitors, GLP-1 receptor agonists, DPP-4 inhibitors, and sulfonylureas on risk of kidney outcomes: emulation of a target trial using health care databases. Diabetes Care. 2020. https://doi.org/10. 2337/dc20-1890.

62. Thein D, Christiansen MN, Mogensen UM, Bundgaard JS, Rørth R, Madelaire $C$, et al. Add-on therapy in metformin-treated patients with type 2 diabetes at moderate cardiovascular risk: a nationwide study. Cardiovasc Diabetol. 2020;19(1):107.

63. Rosenstock J, Kahn SE, Johansen OE, Zinman B, Espeland MA, Woerle HJ, et al. Effect of linagliptin vs glimepiride on major adverse cardiovascular outcomes in patients with type 2 diabetes: the CAROLINA randomized clinical trial. JAMA. 2019. https://doi.org/10.1001/jama.2019.13772.

64. American Diabetes Association. Economic costs of diabetes in the US in 2017. Diabetes Care. 2018;41(5):917-28.

65. Jiao FF, Fung CSC, Wan EYF, Chan AKC, McGhee SM, Kwok RLP, et al. Five-year cost-effectiveness of the multidisciplinary risk assessment and management programme-diabetes mellitus (RAMP-DM). Diabetes Care. 2018;41(2):250-7.

66. Hong D, Si L, Jiang M, Shao H, Ming W-K, Zhao Y, et al. Cost Effectiveness Of Sodium-Glucose Cotransporter-2 (SGLT2) inhibitors, Glucagon-Like
Peptide-1 (GLP-1) Receptor Agonists, and Dipeptidyl Peptidase-4 (DPP-4) inhibitors: a systematic review. Pharmacoeconomics. 2019;37(6):777-818.

67. McEwan P, Morgan AR, Boyce R, Bergenheim K, Gause-Nilsson IAM, Bhatt $\mathrm{DL}$, et al. The cost-effectiveness of dapagliflozin in treating high-risk patients with type 2 diabetes mellitus: An economic evaluation using data from the DECLARE-TIMI 58 trial. Diabetes Obes Metab. 2020. https:// doi.org/10.1111/dom. 14308 .

68. Neuen BL, Ohkuma T, Neal B, Matthews DR, de Zeeuw D, Mahaffey KW, et al. Cardiovascular and renal outcomes with canagliflozin according to baseline kidney function. Circulation. 2018;138(15):1537-50.

69. Perkovic V, Jardine MJ, Neal B, Bompoint S, Heerspink HJL, Charytan DM, et al. Canagliflozin and renal outcomes in type 2 diabetes and nephropathy. N Engl J Med. 2019;380(24):2295-306.

70. Heerspink HJL, Stefánsson BV, Correa-Rotter R, Chertow GM, Greene T, Hou F-F, et al. Dapagliflozin in patients with chronic kidney disease. N Engl J Med. 2020;383(15):1436-46.

71. Leiter LA, Carr MC, Stewart M, Jones-Leone A, Scott R, Yang F, et al. Efficacy and safety of the once-weekly GLP-1 receptor agonist albiglutide versus sitagliptin in patients with type 2 diabetes and renal impairment: a randomized phase III study. Diabetes Care. 2014;37(10):2723-30.

72. Davies MJ, Bain SC, Atkin SL, Rossing P, Scott D, Shamkhalova MS, et al. Efficacy and safety of liraglutide versus placebo as add-on to glucoselowering therapy in patients with type 2 diabetes and moderate renal impairment (LIRA-RENAL): a randomized clinical trial. Diabetes Care. 2016;39(2):222-30.

73. Tuttle KR, Lakshmanan MC, Rayner B, Busch RS, Zimmermann AG, Woodward DB, et al. Dulaglutide versus insulin glargine in patients with type 2 diabetes and moderate-to-severe chronic kidney disease (AWARD-7): a multicentre, open-label, randomised trial. Lancet Diabetes Endocrinol. 2018;6(8):605-17.

74. Mosenzon O, Blicher TM, Rosenlund S, Eriksson JW, Heller S, Hels OH, et al. Efficacy and safety of oral semaglutide in patients with type 2 diabetes and moderate renal impairment (PIONEER 5): a placebo-controlled, randomised, phase 3a trial. Lancet Diabetes Endocrinol. 2019;7(7):515-27.

75. Trulicity ${ }^{\circledR}$ (dulaglutide) is the first and only type 2 diabetes medicine approved to reduce cardiovascular events in adults with and without established cardiovascular disease | Eli Lilly and Company [Internet]. https://investor.lilly.com/news-releases/news-release-details/trulicityrdulaglutide-first-and-only-type-2-diabetes-medicine. Accessed 21 Aug 2020

76. Einarson TR, Acs A, Ludwig C, Panton UH. Prevalence of cardiovascular disease in type 2 diabetes: a systematic literature review of scientific evidence from across the world in 2007-2017. Cardiovasc Diabetol. 2018;17(1):83.

77. Harding JL, Pavkov ME, Magliano DJ, Shaw JE, Gregg EW. Global trends in diabetes complications: a review of current evidence. Diabetologia. 2019;62(1):3-16.

78. Ceriello A, Barkai L, Christiansen JS, Czupryniak L, Gomis R, Harno K, et al. Diabetes as a case study of chronic disease management with a personalized approach: the role of a structured feedback loop. Diabetes Res Clin Pract. 2012;98(1):5-10.

79. Billings LK, Doshi A, Gouet D, Oviedo A, Rodbard HW, Tentolouris N, et al. Efficacy and safety of IDegLira versus basal-bolus insulin therapy in patients with type 2 diabetes uncontrolled on metformin and basal insulin: the DUAL VII randomized clinical trial. Diabetes Care. 2018;41(5):1009-16.

80. Aroda VR, Rosenstock J, Wysham C, Unger J, Bellido D, González-Gálvez $\mathrm{G}$, et al. Efficacy and safety of lixilan, a titratable fixed-ratio combination of insulin glargine plus lixisenatide in type 2 diabetes inadequately controlled on basal insulin and metformin: the LixiLan-L randomized trial. Diabetes Care. 2016;39(11):1972-80.

81. Heller S, Bode B, Kozlovski P, Svendsen AL. Meta-analysis of insulin aspart versus regular human insulin used in a basal-bolus regimen for the treatment of diabetes mellitus. J Diabetes. 2013;5(4):482-91.

82. Hirshberg B, Raz I. Impact of the U.S. food and drug administration cardiovascular assessment requirements on the development of novel antidiabetes drugs. Diabetes Care. 2011;34:S101-6.

83. White WB, Cannon CP, Heller SR, Nissen SE, Bergenstal RM, Bakris GL, et al. Alogliptin after acute coronary syndrome in patients with type 2 diabetes. N Engl J Med. 2013;369(14):1327-35. 
84. Scirica BM, Bhatt DL, Braunwald E, Steg PG, Davidson J, Hirshberg B, et al. Saxagliptin and cardiovascular outcomes in patients with type 2 diabetes mellitus. N Engl J Med. 2013;369(14):1317-26.

85. Green JB, Bethel MA, Armstrong PW, Buse JB, Engel SS, Garg J, et al. Effect of sitagliptin on cardiovascular outcomes in type 2 diabetes. N Engl J Med. 2015;373(3):232-42.

86. Kernan WN, Viscoli CM, Furie KL, Young LH, Inzucchi SE, Gorman M, et al. Pioglitazone after ischemic stroke or transient ischemic attack. N Engl J Med. 2016;374(14):1321-31.

87. Perkovic V, de Zeeuw D, Mahaffey KW, Fulcher G, Erondu N, Shaw W, et al. Canagliflozin and renal outcomes in type 2 diabetes: results from the CANVAS Program randomised clinical trials. Lancet Diabetes Endocrinol. 2018;6(9):691-704.

88. Mosenzon O, Wiviott SD, Cahn A, Rozenberg A, Yanuv I, Goodrich EL, et al. Effects of dapagliflozin on development and progression of kidney disease in patients with type 2 diabetes: an analysis from the DECLARETIMI 58 randomised trial. Lancet Diabetes Endocrinol. 2019;7(8):606-17.

89. McMurray JJV, Solomon SD, Inzucchi SE, Køber L, Kosiborod MN, Martinez FA, et al. Dapagliflozin in patients with heart failure and reduced ejection fraction. N Engl J Med. 2019:381(21):1995-2008.

90. Packer M, Anker SD, Butler J, Filippatos G, Pocock SJ, Carson P, et al. Cardiovascular and renal outcomes with empagliflozin in heart failure. $\mathrm{N}$ Engl J Med. 2020;383(15):1413-24

91. Bhatt DL, Szarek M, Pitt B, Cannon CP, Leiter LA, McGuire DK, et al. Sotagliflozin in patients with diabetes and chronic kidney disease. N Engl J Med. 2020. https://doi.org/10.1056/NEJMoa2030186.

92. Bhatt DL, Szarek M, Steg PG, Cannon CP, Leiter LA, McGuire DK, et al. Sotagliflozin in patients with diabetes and recent worsening heart failure. N Engl J Med. 2020;384:117-28.
93. Gerstein HC, Colhoun HM, Dagenais GR, Diaz R, Lakshmanan M, Pais P, et al. Dulaglutide and renal outcomes in type 2 diabetes: an exploratory analysis of the REWIND randomised, placebo-controlled trial. Lancet. 2019;394(10193):131-8

94. A heart disease study of semaglutide in patients with type 2 diabetesfull text view-ClinicalTrials.gov [Internet]. 2019. https://clinicaltrials.gov/ ct2/show/NCT03914326. Accessed 23 Nov 2019.

95. Dormandy JA, Charbonnel B, Eckland DJA, Erdmann E, Massi-Benedetti $M$, Moules IK, et al. Secondary prevention of macrovascular events in patients with type 2 diabetes in the PROactive Study (PROspective pioglitAzone Clinical Trial In macroVascular Events): a randomised controlled trial. Lancet. 2005;366(9493):1279-89.

96. Marso SP, McGuire DK, Zinman B, Poulter NR, Emerson SS, Pieber TR, et al. Efficacy and safety of degludec versus glargine in type 2 diabetes. N Engl J Med. 2017;377(8):723-32.

97. ORIGIN Trial Investigators, Gerstein HC, Bosch J, Dagenais GR, Díaz R, Jung $H$, et al. Basal insulin and cardiovascular and other outcomes in dysglycemia. N Engl J Med. 2012;367(4):319-28.

\section{Publisher's Note}

Springer Nature remains neutral with regard to jurisdictional claims in published maps and institutional affiliations.
Ready to submit your research? Choose BMC and benefit from:

- fast, convenient online submission

- thorough peer review by experienced researchers in your field

- rapid publication on acceptance

- support for research data, including large and complex data types

- gold Open Access which fosters wider collaboration and increased citations

- maximum visibility for your research: over $100 \mathrm{M}$ website views per year

At BMC, research is always in progress.

Learn more biomedcentral.com/submissions 